\title{
ДИДАКТИЧЕСКАЯ КОМПЕТЕНТНОСТЬ ПРЕПОДАВАТЕЛЕЙ-НОСИТЕЛЕЙ И НЕНОСИТЕЛЕЙ ЯЗЫКА (на примере преподавания иностранного языка в вузах России)
}

\author{
Г.А. Астафьева \\ Московский гуманитарный университет
}

\begin{abstract}
Аннотация: Статья посвящена исследованию вопросов профессиональной компетентности преподавателей носителей и неносителей языка в рамках лингвистического образования в современных вузах России. Приводятся результать опроса студентов, выявляюшие преимущества и недостатки обучения с данными категориями преподавателей. Сделаны выводы о иелесообразности организации занятий как с русскоязычными преподавателями, так и $с$ преподавателями-носителями иностранного языка.
\end{abstract}

Ключевые слова: иностранный язык, профессиональная компетентность, дидактическая компетентность, носитель языка, неноситель языка

\section{DIDACTIC COMPETENCE OF NATIVE AND NON-NATIVE TEACHERS (on the example of teaching a foreign language in Russian universities)}

\author{
G.A. Astafieva \\ Moscow University for the Humanities
}

\begin{abstract}
The article is devoted to the study of teachers 'professional competence among native and non-native speakers in the framework of linguistic education in modern Russian universities. The results of students' questionnaire, identifying the advantages and disadvantages of studying with these categories of teachers, are revealed. The conclusion is drawn about expediency of the organization of classes both with Russian-speaking and native-speaking teachers of the foreign language.

Keywords: foreign language, professional competence, didactic competence, native speaker, nonnative speaker
\end{abstract}

В настоящее время наблюдается повышение внимания к отечественной системе иноязычного образования как со стороны государства, так и общества в целом. Данная тенденция обусловливается фактом восприятия иноязычного образования в качестве стратегического ресурса в социально-экономическом развитии современной России.

В связи с введением ФГОС на всех уровнях образовательной системы повышаются требования к процессу реализации обучения в предметной области дисциплины «Иностранный язык». Все это свидетельствует о существующей необходимости введения системных изменений в языковое образование, а также необходимости подготовки высококвалифицированных кадров для различных типов образовательных учреждений, в том числе и для высшей школы.

Термины «компетентность» и «профессиональная компетентность» вошли в научный обиход отечественных педагогов и психологов в конце ХХ в. Проблемы 
содержания профессиональной компетентности современного педагога находятся в фокусе внимания современных ученых и педагогов-практиков. Отдельные аспекты формирования и становления профессиональной компетентности педагога рассматриваются в работах Г.К. Селевко, А.Г. Бермус, А.В. Хуторского, О.М. Мутовкиной и др. Однако вопросы, связанные с профессиональной компетентностью преподавателя иностранного языка вуза, не получили всестороннего освещения в научной литературе, что обусловливает актуальность нашего исследования.

Качество образования зависит от компетентности педагога, а также от уровня его профессиональной подготовки. Понятие «компетентность» следует рассматривать с точки зрения применения определенных знаний, умений и навыков педагога. По мнению А.В. Хуторского, компетентность это одновременно совокупность личностных качеств педагога (ценностных ориентаций, способностей и т.д.) и способность к осуществлению деятельности в конкретной личностно-значимой сфере (Хуторской, 2005: 12-19). Таким образом, компетентность преподавателя иностранного языка представляет собой систему профессионально-личностных качеств педагога, которая обусловливает эффективность реализации его педагогической деятельности.

Исследователи, изучающие природу компетентности, обращают внимание на такие ее характеристики, как системность и многоаспектность. Качество современного языкового образования большинство ученых рассматривает как системную характеристику сквозь призму понятия «профессиональная компетентность».

Чтокасаетсяпрофессиональнойкомпетентностипреподавателяиностранного языка вуза, то она складывается из общих и профессиональных компетенций взаимообусловливающихся профессиональной культурой и педагогическим мастерством (Алексеева, 2012: 100). Ключевым моментом в данном случае становится готовность преподавателя к осуществлению педагогической деятельности, основывающаяся на многочисленных педагогических умениях, характеризующих эту готовность.

Существуют различные подходы к определению структуры и содержания профессиональной компетенции педагога. Так, Н.В. Кузьмина включает в ее структуру следующие компетентности: специально-педагогическую, социальнопсихологическую, дифференциально-психологическую, методическую, аутопсихологическую (Кузьмина, 1990: 149).

В свою очередь, Л.Е. Алексеева рассматривает базовые (общепедагогический, профессионально-коммуникативный, научно-исследовательский, информационнокоммуникационный)испециальные(предметно-ориентированный,межпредметный) компоненты в структуре профессиональной компетентности преподавателя иностранных языков в вузе (Алексеева, 2012: 100-102). 
Некоторые ученые особо выделяют дидактическую компетентность в качестве важнейшего компонента профессиональной компетентности педагога (Храмова, 2012). Дидактическая компетентность - это ключевой компонент профессиональной компетентности педагога, отражающий характеристики уровня профессионализма и выражающийся в субъектности педагога при организации дидактического процесса (Шиткина, 2013: 61-65). Сущность дидактической компетенции проявляется в готовности преподавателя эффективно организовывать процесс обучения иностранному языку, опираясь на большой дидактический потенциал, в способности к накоплению и творческому преобразованию знаний в сфере дидактики высшей школы. На наш взгляд, данная компетентность выступает критерием оценки деятельности преподавателей вуза, а также непосредственно самих учащихся.

По мнению Э. Шиткиной (Шиткина, 2013), дидактическая компетентность предполагает наличие у преподавателя:

- предметных знаний (глубинных знаний в области преподаваемой дисциплины);

- предметно-дидактических знаний (знаний специфики методики преподавания дисциплины);

- психолого-педагогических знаний (сведений об особенностях организации педагогической деятельности и общения в корреляции с психофизиологическими особенностями развития учащихся);

- организационные знания (знаний о структуре планирования и организации различных типов занятий, методах педагогического руководства).

Благодаря совокупности этих знаний при организации дидактического процесса педагог становится носителем субъектных качеств, т.к. он осознает цели образовательной деятельности, имеет субъектную позицию, представления о выстраивании индивидуальной образовательной траектории студентов в соответствии с их способностями и склонностями, а также способен к рефлексии и личностному росту.

Привлечение в образовательный процесс компетентных специалистов является актуальной задачей для российских вузов. Для обеспечения качественного иноязычного образования студентов занятия проводятся опытными преподавателями, имеющими соответствующую квалификацию и ученую степень. Кроме того, руководство образовательных организаций прибегает к помощи преподавателей-иностранцев, являющихся носителями того или иного языка.

Необходимо отметить, что главная ценность привлечения к преподаванию носителей языка состоит в аутентичности вербального и невербального поведения, т.е. естественности лексического и грамматического выражения мысли, ситуативной адекватности употребления языковых и неязыковых средств 
в соответствии с принятыми нормами (Харламова, 2018: 141). Естественность коммуникации носителя языка вызывает познавательную активность студентов, положительно влияет на мотивацию, оптимизируя процесс обучения (Luksha, 2006: 97). Однако владения языком в совершенстве недостаточно для обеспечения качественного обучения студентов, не стоит забывать о необходимых при преподавании языка компетенциях. Зачастую носители языка не имеют педагогического образования, подтвержденного соответствующими международными сертификатами и дипломами. Подобные случаи могут свидетельствовать о низкой дидактической компетентности носителя языка, несмотря на то что преподаваемый им язык является для него родным.

Опираясь на содержание понятия «профессиональная компетентность», мы сформулировали основные показатели оценки профессионального потенциала преподавателей иностранного языка в вузе:

1. Владение современными образовательными технологиями и их реализация в профессиональной деятельности (т.е. необходимость организации образовательного процесса с учетом современных требований к качеству образования и уровню подготовки учащихся).

2. Готовность осуществлять педагогическую деятельность и решать профессиональные задачи (выражается в высокой мотивации выполнения профессионально-педагогической деятельности, соответствии и адаптации к требованиям к профессиональным ролям).

3. Владение профессионально-речевой культурой и ориентация на различные области духовной культуры как характеристика богатства личности педагога (соблюдение норм и этики профессионального общения).

4. Способность к рефлексии и самоконтролю профессионально-педагогической деятельности в соответствии с принятыми нормами и стандартами (способность фиксировать проблемы в профессиональной деятельности, трансформировать ее за счет внутренних ресурсов, повышая уровень самоорганизации и вырабатывая индивидуальный стиль профессиональной деятельности).

Для того, чтобы определить профессиональный потенциал преподавателей носителей и неносителей языка нами было проведено исследование на базе Института Конфуция при МГЛУ. 20 респондентов были опрошены на предмет опыта изучения иностранного языка с преподавателями-носителями языка и русскоговорящими преподавателями. В группу опрашиваемых входили студенты возрастной категории от 15 до 30 лет, представляющие различные социальные группы (учащиеся школы; студенты различных вузов г. Москвы по специальностям (экономика, международные отношения, туризм, педагогика, программирование, лингвистика, журналистика), преподаватели, переводчики, представители сферы бизнеса, туризма и банковского дела).

Студентам предлагалось ответить на вопросы и назвать наиболее 
Научные труды Московского гуманитарного университета

2020 № 6

оптимальный на их взгляд способ изучения иностранного языка (с носителем/ неносителем языка), обозначить преимущества и недостатки подобного обучения и определить роль родного языка при изучении иностранного. Полученные результаты представлены в таблице 1.

\section{Результаты опроса студентов об опыте изучения иностранного языка с преподавателями не/носителями языка}

\begin{tabular}{|c|c|c|}
\hline \multirow[b]{2}{*}{ Вопрос анкеты } & \multicolumn{2}{|c|}{ Ответы респондентов } \\
\hline & $\begin{array}{c}\text { С преподавателем } \\
\text { не носителем языка }\end{array}$ & $\begin{array}{c}\text { С преподавателем- } \\
\text { носителем языка }\end{array}$ \\
\hline $\begin{array}{l}\text { 1.Какой способ изучения ИЯ } \\
\text { самый лучший? }\end{array}$ & $60 \%$ (12 чел.) & $40 \%$ (8 чел.) \\
\hline $\begin{array}{l}\text { 2.Назовите преимущества из- } \\
\text { учения ИЯ с преподавателем } \\
\text { не/носителем языка }\end{array}$ & $\begin{array}{l}\text { 1. Объяснение учебного ма- } \\
\text { териала на родном языке сту- } \\
\text { дентов - } 40 \% \text { (8 чел.). } \\
\text { 2. Знание особенностей пре- } \\
\text { подавания в данной наци- } \\
\text { ональной аудитории - } 40 \% \\
(8 \text { чел.). } \\
\text { 3. Возможность сопостав- } \\
\text { ления родной и иноязычной } \\
\text { культуры - } 20 \% \text { (4 чел.) }\end{array}$ & $\begin{array}{l}\text { 1. Возможность погружения } \\
\text { в иноязычную среду }-50 \% \\
(10 \text { чел.). } \\
\text { 2. Постановка аутентичного } \\
\text { произношения }-25 \% \text { (5 чел.). } \\
\text { 3. Обучение актуальной лек- } \\
\text { сике (сленг/диалект) - 25\% } \\
(5 \text { чел.) }\end{array}$ \\
\hline $\begin{array}{l}\text { 3. Назовите недостатки изу- } \\
\text { чения ИЯ с преподавателем } \\
\text { не/носителем языка }\end{array}$ & $\begin{array}{l}\text { 1. Несовершенство фонетики, } \\
\text { недостаточность знаний акту- } \\
\text { альной лексики - 60\% (12 чел.). } \\
\text { 2. Снижение доли практики } \\
\text { языка - 40\% (8 чел.) }\end{array}$ & $\begin{array}{l}\text { 1. Трудности восприятия речи } \\
\text { на начальном этапе обучения - } \\
50 \% \text { ( } 10 \text { чел.). } \\
2 . \quad \text { Профессионально-педа- } \\
\text { гогический аспект - } 50 \% \\
\text { (10 чел.) }\end{array}$ \\
\hline $\begin{array}{l}\text { 4. Помогает ли родной язык } \\
\text { на занятиях по ИЯ? }\end{array}$ & $\begin{array}{l}\text { Да }-80 \% \text { (16 чел.) } \\
\text { Нет }-20 \% \text { (4 чел.) }\end{array}$ & Нет $-100 \%$ (20 чел.) \\
\hline
\end{tabular}

Результаты опроса показали, что студенты имеют положительный опыт изучения иностранного языка с русскоговорящими преподавателями $(60 \%)$. В рамках подобного обучения среди преимуществ были названы возможности предъявления учебного материала на родном языке $(40 \%)$ и знания специфики русскоязычной аудитории учащихся (прогнозирование и коррекция типичных ошибок, вызванных интерференцией русского языка) (40\%). Также немаловажной для студентов является возможность сопоставления родной и иноязычной культуры (20\%).

$40 \%$ опрошенных высказались за обучение с преподавателем-носителем языка. При этом главным достоинством аутентичного обучения иностранному языку была названа возможность погружения в иноязычную среду (50\%). Постановка аутентичного произношения (25\%) и обучение актуальной лексике $(25 \%)$ также упоминались среди преимуществ. 
Очевидными недостатками русскоязычных преподавателей выступают несовершенства знаний в области фонетики и актуальной лексики $(60 \%)$ и снижение доли практики языка вследствие использования на занятиях родного языка учащихся (40\%). Вместе с тем, половина респондентов указала на трудность восприятия иностранной речи преподавателей-носителей языка, особенно на начальном этапе, недостаточную компетентность при организации обучения (отсутствие знаний о менталитете, методиках обучения, актуальных для данной национальной аудитории студентов). Большинство студентов также высказались за использование родного языка на занятии (80\%) для доступности объяснения грамматики, проведения аналогий, сопоставлений и т.д.

В целом языковой опыт студентов показал целесообразность организации обучения как с преподавателем носителем языка, так и с русскоговорящим преподавателем в зависимости от аспекта дисциплины и этапа изучения языка.

Подводя итоги, отметим, чтопоказателемвысокогоуровняпрофессионализма преподавателя вуза является дидактическая компетентность, предполагающая наличие у педагога готовности эффективно организовывать процесс обучения иностранному языку. Русскоязычные преподаватели в процессе обучения в полной мере реализуют богатый дидактический потенциал, используя психологопедагогические и организационные знания, в то время как возможность погружения в иноязычную среду может обеспечить исключительно носитель языка. Для повышения качества образования целесообразна организация совместной работы русскоязычного преподавателя с носителем иностранного языка при учете этапа обучения (начальный/продвинутый), уровня языковой подготовки студентов, а также специфики аспекта дисциплины (фонетика/ лексика/грамматика и т.д.).

\section{СПИСОК ЛИТЕРАТУРЫ}

Алексеева Л.Е. (2012) К вопросу о профессиональной педагогической компетентности преподавателя иностранного языка вуза// Вестник СанктПетербургского университета. Сер. 9. (Вып. 2). С.98-106.

Кузьмина Н.В. (1990) Профессионализм личности преподавателя. М.: АПН. $149 \mathrm{c}$.

Харламова М.В. (2018) Аутентичность как критерий привлечения носителей языка к процессу обучения иностранным языкам //Материалы Международного научно-практического семинара. М.: МГПУ, Канцлер, С.140-143.

Храмова Е.В. (2012) Развитие дидактической компетентности преподавателя вуза: Дис. канд. пед. наук. 224 с.

Хуторской А.В. Технология проектирования ключевых и предметных компетенций /A.В. Хуторской// Интернет-журнал «Эйдос». [Электронный реcypc]. -URL: http://www.eidos.ru/journal/2005/1212.htm (дата обращения 24.03.2019). 
Шиткина Э. (2013) Дидактическая компетентность учителя как основной компонент профессионально педагогической компетентности // Педагогические науки. №12. С.61-65.

Luksha I.V., Solovova E.N. (2006) Pros and Cons for Using non/native English Speaking Teachers// Вестник ТГПУ. Серия: Гуманитарные науки. №9. - С.97-99.

Астафьева Галина Алексеевна - магистрант 3 курса кафедры педагогики и психологии высшей школы Московского гуманитарного университета. Научный руководитель- профессор кафедры педагогики и психологии высшей школы Л.В. Романюк. Адрес: 111395, Россия, г. Москва, ул. Юности, д. 5. Тел.: +7(965)35382-77. Эл. адрес: red-poppy-96@mail.ru

Astafieva Galina Alekseevna - Master's student, 3rd year, Department of Pedagogy and Psychology of Higher Education, Moscow University for the Humanities, scientific adviser- Professor of the Department of Pedagogy and Psychology of Higher School L.V. Romanyuk. Address: 111395, Russia, Moscow, st. Yunosti, 5. Tel .: +7 (965) 353-82-77. Email address: red-poppy-96@mail.ru

\section{Для цитирования:}

Астафьева Г.А. Дидактическая компетентность предподавателей-носителей и неносителей языка (на примере преподавания иностранного языка в вузах России) // Научные труды Московского гуманитарного университета. 2020. №6. С. 4-10. DOI: https://www.doi.org/10.17805/trudy.2020.6.1 